\title{
Gondolatok a mesterséges intelligencia egyes polgári jogi kérdéseiről
}

\author{
Auer Ádám \\ Nemzeti Közszolgálati Egyetem, Budapest, Magyarország \\ Beérkezett: 2021. 04. 30.; Elfogadva: 2021. 05. 31.
}

\section{Összefoglalás}

\begin{abstract}
A tanulmány kezdő axiómája a mesterséges intelligencia biztonságos alkalmazása. A biztonságos alkalmazás egyik aspektusa a jogi biztonság, az a jogi környezet, amelyben a felmerülő jogi kérdések rendezésére alkalmazható keretrendszer áll rendelkezésre. A tanulmány a Semmelweis Egyetem projektjében fejlesztett mesterséges intelligencia alkalmazásának olyan polgári jogi problémáit vizsgálja, amelyek a mindennapi hasznosítás során merülhetnek fel. A tanulmány következtetése szerint a vizsgált mesterséges intelligencia szerzői mưnek minősül és több védelmi forma is alkalmazható. A jogi szabályozás de lege ferenda kiegészítésre szorul a szerzôi mú folyamatos változása okán. Szükséges rögzíteni egy referenciapontot, amely a felelősség kiindulópontjául szolgál.
\end{abstract}

Kulcsszavak: polgári jog, mesterséges intelligencia, felelősség, szoftver, szerzői mú

\section{Reflections on certain civil law aspects of artificial intelligence}

\author{
Ádám Auer \\ Ludovika - University of Public Service, Budapest, Hungary
}

\begin{abstract}
Summary
The starting point of the study is the safe use of artificial intelligence. Legal certainty is one aspect of safe usage, the legal environment in which a framework is available that can be used to resolve legal issues. The paper examines the civil law issues that may arise in the everyday use of the artificial intelligence application developed within the Semmelweis University project. The study will first focus on the legal protection of the Semmelweis AI, including whether this protection is currently international, regional (European Union) or national and which of these is the optimal choice. The study also reflects on the legislative preparatory work of the European Union in this regard. Our hypothesis is that the majority of civil law areas concerning AI can be regulated within a contractual framework. The AI software developed by the project is a forward-looking medical and practical solution. If we want to use a legal analogy, we can imagine its operation as if we had a solution that could analyse all the national court decisions in each legal field and provide an answer to the legal problem at hand, while simultaneously learning and applying the latest court decisions every day. For this AI solution, the diagnostic process must be carefully examined in order to identify the legal problems. I believe that the optimal solution is to classify this AI application as 'software' because this allows property rights to be acquired in their entirety and it opens the door to clarifying individual associated usage and copyright by contract. An important civil law question arises in relation to parallel copyright protection, when the individual personal contributions (creative development work) to the software cannot be separated. Therefore, it is important to record the process and to separate the individual contributions protecting by copyright. The AI plays a questionable role in the diagnostic process. If the software itself cannot make a decision, but only provides a framework and platform, then it will not be entitled to co-ownership relating to the diagnostic images (e.g. just as a camera will not own the rights to the pictures taken with it). However, if the algorithm is part of the decision-making (e.g. the selecting of negative diagnoses), it would possibly be co-owner of the right, because it was involved in the development of the classification. All this should be clearly stated in the licence agreement, based on full knowledge of the decision-making process. However, de lege ferenda, the legal regime needs to be supplemented in view of the constant changes of the copyright work and the changing authors. There is a need to establish a specific point in the legislation that serves as a reference point for liability and legal protection. The issues under consideration are of a legal security nature, since without precise legal protection both the creator of artificial intelligence and the persons who may be held liable in the event of a malfunctioning of such systems may be uncertain.
\end{abstract}

Keywords: civil law, artificial intelligence, liability, software, copyright protection 


\section{Bevezetés}

Jelen tanulmány alkalmazott tudományos céllal készült. A Semmelweis Egyetem projektjében fejlesztett mesterséges intelligencia $(\mathrm{MI})$ alkalmazásának olyan polgári jogi kérdéseit vizsgálja, amely a mindennapi hasznosítás során merülhet fel. A Semmelweis Egyetem Egészségügyi Közszolgálati Karának Egészségügyi Menedzserképző Központja és az Eötvös Loránd Tudományegyetem Természettudományi Karának Fizikai Intézet Komplex Rendszerek Fizikája Tanszéke 2019-ben indította azt a közös projektet, amelyben a képi feldolgozást végző mesterséges intelligencia eljárások napi orvosi gyakorlatba történő átültetését vizsgálta, illetve mintaalkalmazásokat és eljárásokat dolgoz ki ennek keretében. A projekt fó célja, hogy az MI segítségével a népegészségügyi szempontból jelentős két betegség, a vastagbéldaganatok és az emlódaganatok diagnosztikai eljárásait segítse, az orvosi döntést támogassa. A vastagbéldaganatok esetében, a szövettani metszetek digitalizálását követően egy tanító eljárás támogatásával a metszeteken a mesterséges intelligencia jelöli meg a szövettanilag kérdéses területeket, jelezve azt is, hogy milyen jellegú elváltozást „gondol” a gép a képi mintázat alapján. Az emlődaganatok esetében a mammográfiás képalkotásnál fejlesztettek hasonló folyamatot. A két eljárás kidolgozásával és a teszteléseket követő bevezetéssel lehetőség nyílhat az országos kiterjesztésre és a széles körü alkalmazásra.

A tanulmány hipotézise, hogy a mesterséges intelligencia alkalmazásának megkerülhetetlen kérdése, hogy maga az a - leegyszerúsítve - szoftverre, adatbázisra épülő eszköz, amely a napi múködésbe lép, csak biztonságosan legyen használható. Ennek egyik garanciája, ha az eszköz jogi védelme tisztázásra kerül, ugyanis ez elengedhetetlen ahhoz, hogy a napi múködés biztonságos legyen. Megfelelő jogi védelem nélkül ezek a rendszerek nem alkalmazhatóak. A polgári jog, ezen belül a szellemi alkotások joga nyújtja jelenleg azt a védelmi rendszert, amely a mesterségesintelligencia-megoldásokra alkalmazható. A probléma jogbiztonsági kérdés, ugyanis egzakt jogi védelem nélkül bizonytalan lehet mind az alkotó, mind azon személyek köre, akik ilyen rendszerek múködése következtében kárt szenvednek. A tanulmány első felében a mesterséges intelligencia biztonságos múködése kapcsán elengedhetetlen koncepcionális kérdéseket elemezzük, ezt követően pedig a projektben kifejlesztett megoldás jogi védelmének lehetséges formáit vizsgáljuk.

A jogi gondolkodás a mesterséges intelligencia kapcsán kétoldalú (Zödi 2018). Egyrészt magas igénnyel megfogalmazott elméleti elgondolások látnak napvilágot, amely párosul azzal, hogy a mesterséges intelligencia napi alkalmazásának elemi jogi kérdései sincsenek tisztázva (ehhez a tisztázó munkához alapmunkát jelentenek: Klein-Tóth, 2019 és Scherer 2016).

\section{A jogi szabályozás szintjei és lehetséges irányai}

A jogi szabályozásnak hagyományosan elkülönült szintjei a nemzetközi, a regionális (uniós) vagy állami szabályozások. A mesterséges intelligencia kapcsán ez azért egy vizsgálandó kérdés, mert a mesterséges intelligencia túlnyomórészt globális környezetben múködik. Ha egy magyar orvosi mûszert vizsgálunk, akkor például tetten érhető, hogy egyes alkatrészei különböző országokból (akár az Európai Unión kívülrőll) érkeztek, az eszköz az Európai Unióban került végfelhasználói elóállításra, a magyar hatóságok engedélyezték vagy eloórták az alkalmazását, a szoftver support támogatása közvetlenül a gyártótól érkezik. Mindezek nagymértékben határozhatják meg az alkalmazandó jogot az egyes jogi problémákra, így a felek jogválasztása is előtérbe kerülhet.

A jogtudományi megközelítés szempontjából talán közhelyes, de utalnunk kell rá, hogy véleményünk szerint a nemzetközi jogi szabályozás általános elveket garantálhat, követelményeket támaszthat és alapvető fogalmakat tisztázhat, de a napi múködésben, a mindennapi jogalkalmazási kérdésekben aligha lehet hatékony szabályozási szint; kétséges továbbá az is, hogy a mindennapi használathoz alkalmazandó speciális, egyedi kérdésekben a jogi szabályozás nemzetközi szinten lenne a legoptimálisabb. Az Európai Unió mint Magyarország szempontjából regionális együttmúködés már más szabályozási keretet tud adni. Az EU jog által szabályozott területeken lehetséges olyan jogforrás elfogadása, amely közvetlen hatállyal és elsőbbséggel bír a tagállami joggal szemben, azaz az uniós szabály megelőzi a tagállami normát, így ha a mesterséges intelligencia uniós normatív rendelkezései hatályba lépnek, akkor a tagállami megoldás szükségképpen másodlagos lehet. A mesterséges intelligencia témaköréhez kapcsolódóan az EU már fogadott el jogszabályokat (pl.: GDPR - EU/2016/679 rendelet, Szoftver irányelv), de nagyobb részben az előkészítési fázisában tart a munka, melynek jelentős állomása az, hogy az Európai Bizottság - a tanulmány lezárásának időpontjában - tette közzé a mesterséges intelligenciáról szóló jogszabályjavaslatot, melyet a tanulmányban később még érintünk.

Véleményünk szerint a tagállami, hazai szabályozás képes választ adni a mesterséges intelligencia általunk vizsgált kérdéseire, de itt is egy olyan előkészítő munka (például a Mesterséges Intelligencia Koalíció által készített Stratégia) zajlik, melynek várható eredményei az uniós joggal egy idóben látszódhatnak csak.

A tanulmány tudatosan nem de lege ferenda szabályozást mutat be, hanem a jelen szabályozási állapotból indul ki. A hatályos megoldás egyébként már most is tükrözi a fenti rendszert: tetten érhetőek a nemzetközi egyezményeken nyugvó szabályok a szellemi alkotások terén, az uniós jogi rendelkezések például a szoftver esetén és az adatvédelmi kérdésekkel kapcsolatban. A mostani tendenciákat látva kijelenthető, hogy a szabályozási 
megoldásban az Európai Unió kezdeményező szereppel lép fel, és az EU versenyképességének biztosítása céljából elsődlegesen uniós szinten képzeli el a szabályozást. Ennek formája lehet ugyan a tagállami jog számára csak az irányok meghatározása, de a Fehér könyv alapján úgy látszik, hogy az EU vezetése minden tagállam számára közös koncepciót és ehhez kapcsolódó harmonizált (rendeleti) szabályozást irányoz elő (Javaslat 2021).

Fontos felhívni ugyanakkor a figyelmet arra, hogy jogszabályi rendezés jelenlegi hiánya nem jelenti azt, hogy egyes egyedi szerződéses megállapodásokban ne lehetne a kívánt szabályozási tartalmat megalkotni. A szerződéses konstrukció esetén ugyanakkor hátrányok is jelentkeznek: a tárgyalások elhúzódása, egyedi feltételek megalkotása, valamint ha sikerül is megállapodni, akkor az esetleges jogviták rendezése.

A szabályozási koncepció nem szorítkozhat a mesterséges intelligenciát elóállító és a mesterséges intelligencia alkalmazása által közvetlenül érintett (természetes) személy közötti viszonyrendszerre, hanem például az egészségügyi szektorban azokra a személyekre is tekintettel kell lennie, akik az előbbi kapcsolaton belül helyezkednek el, például az egészségügyi szolgáltatók, amelyek mesterséges intelligenciával összefüggő eszközt alkalmaznak.

\section{Alkotmányjogi kontextus}

A szabályozás másik kiindulópontja, az alkotmányos alapjogok fokozott védelme. Habár a tagállami alkotmányjog és az európai alapjogvédelem (Emberi Jogok Európai Bírósága, Európai Bíróság Alapjogi Charta) egyaránt széles körben garantálnak alapvetố jogokat, a mesterséges intelligencia alkalmazásában rejlő kockázat involválja a fokozott alapjogvédelmi szabályozást. Elsődlegesen a személyes adatok védelme, a magánszféra védelme, a diszkrimináció tilalma azok az alapjogok, amelyeket az elókészító dokumentumok is kiemelnek (Fehér könyv 2020). De ugyanígy kérdés lesz a közérdekú adatok nyilvánossága és felhasználhatósága (amint a másodlagos adatfelhasználás bármely állami intézmény részéról elindul), valamint a tulajdonhoz való jog (az adat forgalomképessége eredményezheti azt, hogy a személyes adatok védelme mellett tulajdonjogi igény is keletkezik) egyes rendelkezéseinek értelmezése. A gyakorlati alkalmazása jelenleg még kétséges, de az biztosan kijelenthető, hogy a mesterséges intelligencia fejlesztése nem járhat az alapjogvédelmi elóírások és követelmények védelmi szintjének esetleges csökkentésével. Azaz a mesterséges intelligencia nem szoríthatja háttérbe az alapjogok védelmét egy esetleges konkuráló helyzetben. Ennek eszközei véleményünk szerint elsősorban az adatvédelmi követelményekre: az adatok felhasználásának arányossága, a tárolás szükségességének indokolásában és annak rendszeres felülvizsgálatában; továbbá a tájékoztatási kötelezettségben és az adatbiztonsági kérdésekben ölthetnek testet. Véleményünk sze- rint az elóbbi, vagy ezekhez hasonló eszközök lehetnek azok, amelyek biztosíthatják a megfelelő alapjogi védelmet. Ez a koncepció tükröződik vissza az Európai Bizottság Javaslatában is, a felhasználók részére nyújtott tájékoztatási kötelezettséggel kapcsolatban (Javaslat 2021 Art. 13.).

A fokozott alapjogi törekvés véleményünk szerint tetten érhető egyrészt a GDPR kapcsán, de érzékletesebb a véleménynyilvánítás szabályozásában látni azt a napirenden lévő jogalkotási kérdést, amely tagállami hatáskörben szabályozná például a Facebookon megjelenő posztok jogkövetkezményét, lényegében a Facebook saját jogorvoslati fórumának lehetősége is egy erőteljes reakció a véleménynyilvánítás szabadságának védelmében. Véleményünk szerint az alapjogi meghatározó befolyása nemcsak nemzetközi és regionális szinten valósul meg, hanem ez elsősorban a tagállami gyakorlaton fog alapulni és azok szerepét erősítheti. Ennek egyik közvetett alapja lehet a német Szövetségi Alkotmánybíróság 2019 novemberében hozott két döntése, mely szerint az uniós jog által harmonizált szabályoknál az uniós alapjogokat kell a tagállamnak és a tagállami alkotmánybíróságnak alkalmaznia. Ez egy új út a jogérvényesítésben, és az állampolgárok számára egy lehetőség, hogy a tagállami alkotmányos szabályok mellett az uniós alapjogi rendelkezéseket is felhívják alkotmányjogi sérelmeik és vitájuk során (Auer-Orbán 2020). Azaz, amennyiben az uniós jog harmonizált mesterségesintelligencia-szabályokat alkot, akkor azok alapjogi bíráskodás körébe tartozó jogérvényesítési eljárásai a tagállami alkotmánybíróságokon is megindulhatnak, az Alapjogi Chartát értelmezve.

Az alkotmányjogi környezethez tartozik az a szakpolitikai irány is, amely a fogyasztóvédelem eszközrendszerét igyekszik kiterjeszteni a mesterséges intelligencia alkalmazására. Ennek legnagyobb hátránya a vállalkozás és fogyasztó közötti reláció, azaz az, hogy jelenleg ezek a szabályok vállalkozás és természetes személy fogyasztó között értelmezhetőek, így szabályozást igénylő kérdés az, hogy egy egészségügyi szolgáltató minősülhet-e fogyasztónak a gyártóval szemben.

\section{Az Európai Unió szakpolitikai és jogalkotási javaslatai}

Az Európai Unió jelenleg a jogalkotási előkészítési fázisában tart, melynek fontos mérföldköve a mesterséges intelligencia alkalmazásával kapcsolatos rendelettervezet, melyet az Európai Unió Bizottsága 2021. április 21-én tett közzé. Habár a jogalkotási javaslat még a tárgyalások előtti szakaszban tart, úgy véljük, ez a jogszabálytervezet alkalmas arra, hogy a mesterséges intelligencia jogi szabályozásának alapjait uniós szinten rögzítse.

Az Európai Unió elókészítő munkája kettős célt tartott szem előtt: a gazdasági érdekek érvényesítését és az Európai Unió gazdasági helyzetének javítását, másrészt az ehhez kapcsolódó szabályozás biztonságát és az elért jogbiztonsági szabályozási színvonal megtartását, lehe- 
tőség szerint emelését. Az Európai Bizottság 2020 tavaszán három dokumentumot bocsátott ki: a Fehér könypet a mesterséges intelligenciáról, Az európai adatstratégiát és egy Jelentést, amely a polgári jogi felelősségi szabályok alkalmazásáról szól. Az uniós jogalkotás jelenlegi gondolkodásának egyik kiindulópontja az Európai Parlament 2017. február 16-i állásfoglalása a Bizottság számára a robotikára vonatkozó polgári jogi szabályokról. Az állásfoglalás az általános elvek mellett részletes ajánlásokat tartalmaz a robotikával foglalkozó fejlesztőknek is. A témánkhoz ez két kérdésen keresztül is kapcsolódik. Egyrészt az állásfoglalás nevesít külön területeket, amelyek az egészségügyhöz kapcsolódnak: kitér az orvosi robotokra (sebészi robotokra), ahol az alapelv a felelősség szempontjából továbbra is az marad, hogy a végső döntés mindig az emberi sebész hatáskörében maradjon, másrészt az emberi test javítása és az embertökéletesítés alfejezet tartalmaz szabályozandó célokat (pl.: etikai problémák kezelése, robotprotézisek karbantartása stb. szabályozása). A másik kapcsolódó kérdés pedig az, hogy a dokumentum a polgári jogi kártérítési szabályok újragondolását tartja szükséges azzal, hogy nem lehet szakítani a teljes kártérítés elvével és a kártérítés formáinak korlátozására sem kerülhet sor pusztán azért, mert nem emberi lény okozta a kárt. Az állásfoglalás felveti annak lehetőségét, hogy ezt a felelősségi alakzatot a jogalkotó objektív formában szabályozza. A felelősség klasszikus (hatályos) rendszeréhez képest az előrelépést és az eltérő szabályozás indokát az EP abban látja, hogy az a személy, akinek ráhatása van a robotra (mesterséges intelligenciára), úgymint: aki tanítja, felügyeli etc. eltérő mértékben képes a robot tevékenységét (így a károkozását) is befolyásolni. Ezért szükséges az, hogy a felelősség szempontjából arányosításra kerüljön sor. Az objektív felelősségi formából következően az EP-állásfoglalás a kötelező gépjármü-felelősségbiztosítás mintájára képzeli el a biztosítási formát, kiegészítve egy vagyoni alappal (Pusztahelyi 2020). Végül felmerül az is, hogy a robotok speciálisan jogalanyisággal rendelkezzenek (Keserü 2020).

A mesterséges intelligenciáról szóló Fehér könyv két alapkövetelményt törekszik összhangba hozni: a beruházásösztönzést a mesterségesintelligencia-iparba és a biztonságos alkalmazási környezetet. A Fehér könyv az egészségügyi rendszert példaként hozza fel a szakpolitikai javaslatoknál mint olyan szolgáltatást, mely az emberi élet minőségén javít. A Fehér könyv egy újabb adathullámra kíván hatékony stratégiai javaslatot alkotni. Az egyik ilyen beavatkozás a kiválósági ökoszisztéma, mely támogatja a mesterséges intelligencia terjedését és fejlesztését. A témánk szempontjából kiemelhető, hogy a Fehér könyv célként határozza meg a mesterséges intelligencia közszektor általi elfogadását, melyben az egészségügyet egyedileg is prioritásként kezeli. A Fehér könyvvel együtt kibocsátott dokumentum szintén példaként hozza az egész anyagban az egészségügyet (személyre szabott orvoslás). Az anyag előirányozza a GDPR felülvizsgálatát. Problémaként azonosítja a közszektor adat- állományának kihasználatlanságát, mind a B2G (vállalkozás és kormányzat), mind a G2B (kormányzat és vállalkozás) relációban. Lényeges és nem feltétlenül tartható rossz iránynak az a megközelítés, amely a személyes adatok kapcsán az egyéneknek nagyobb önrendelkezést biztosítana, melynek keretében az egyén maga kezelhetné a hozzájárulásait a személyes adatainak a felhasználásához. Kiemelésre kerül a stratégiában a kiberbiztonság kérdése, mely abban jelent módosítást, hogy az új adatparadigma szerint kevesebb adatot tárolnak majd adatközpontokban, pereminformatikai megoldások szélesebb körben való alkalmazása lesz jellemző.

Az Európai Unió ezt követően jutott abba a jogalkotási előkészítési szakaszba, hogy normaszöveg-tervezetet készítsen el a mesterséges intelligenciával kapcsolatban. A szabályozás célja a bizalom kiépítése a mesterséges intelligenciával szemben, valamint a biztonságos múködtetés követelményeinek az elérése. A szabályozás kockázatértékelésen alapul: elfogadhatatlan, magas (egyes egészségügyi termékek ide tartoznak), szigorú, korlátozott és minimális kockázat között tesz különbséget. A különböző kockázati szintekhez eltérő megfelelőségértékelési, minőségbiztosítási, nyilvántartásba-vételi, és folyamatos felülvizsgálati kötelezettség áll fenn. A kockázati szintekre a javaslat példákat is hoz, segítve egyes rendszerek kockázati besorolását. A mesterségesintelligencia-rendelet tervezete vélhetően termékeny vitát indukál és a szabályozás versenyképességi tényezői mellett a biztonság és a bizalom kiépítésében múködhet közre. A rendelet jelenlegi szövegváltozata véleményünk szerint a korábbi szakértői, konzultációs anyagokon alapuló, aktuális és nem elkésett jogi szövegtervezetet, amely jelentős előrelépés a mesterséges intelligencia jogi kezelésében, és versenyelőnyre tehet szert az EU, amennyiben közös jogszabállyal orientálja és egységesíti a tagállami jogalkotókat.

\section{Az MI tanulmányban használt fogalma}

A fentiekben a mesterséges intelligencia széles értelemben vett szabályozásának várható irányaival és aktuális állásával foglalkoztunk, a továbbiakban a tanulmány alapját képező projektfejlesztési eredmény szellemi alkotások joga szerinti védelmi lehetőségeket tekintjük át.

A mesterséges intelligencia általánosan elfogadott definiálásával továbbra is adós a jogtudomány és a jogi szabályozás. Természetesen találhatóak jogirodalmi álláspontok és fogalomalkotási kísérletek, de arra nem találunk egységes és jó választ, hogy miként kell a mesterséges intelligenciát, mesterséges intelligenciához kapcsolódó jelenségeket (robot) jogi értelemben kezelni (Gaszt 2019; Kovács-Czékmann-Ritó 2020).

A jogi szakirodalom túlteng azon megállapításoktól, hogy ki írta le először a robot szót, hogyan múködik az önvezető autó olyan helyzetben, ahol emberi életek közötti választás állhat fenn. A tanulmánynak nem tárgya és nem is célja ezen elméletek bemutatása és értékelése. Szükségesnek mutatkozik azonban az, hogy a tudo- 
mányágak párbeszédében egy viszonyítási pontot jelöljünk ki.

A legérzékletesebben véleményünk szerint jogi szempontból az EU Fehér Könyve definiálja a mesterséges intelligenciát: „a mesterséges intelligencia olyan technológiák együttese, amelyek adatokat kombinálnak algoritmusokkal és számítási teljesítménnyel" (Fehér Könyv 2020). Azaz két fogalmi elem, ami jogi szempontból releváns: adat + algoritmus +/- szoftver. Habár a tételes jog még nem ad definíciót, de az már egy lényeges elmozdulás, hogy nem feltétele jogi szempontból a mesterséges intelligenciának a fizikai megvalósulás, azaz a fizikai lét (robot). Ezzel összhangban áll a Javaslat 2021 Art. 3. (1) bekezdése is.

\section{A mesterséges intelligencia lehetséges hazai jogi védelme}

A mesterséges intelligencia vizsgált esete véleményünk szerint szellemi alkotásnak minősül. A szellemi alkotások jogi védelmi rendszerében több oltalmi, védelmi forma is alkalmazható: akár az ötletek (know-how) védelmétől indulva jutunk el a két nagy rendszerig, a szabadalmakig és a szerzői múvekig. A szoftver önálló szerzőimü-kategória. Időról időre felvetődik a szabadalmi besorolás és a szoftver iparjogvédelmi alkotási védelmének szükségessége, de mind ez idáig ez felvetés szintjén maradt (AuerPapp 2014; Schuster 2018). A védelmi formák átfedése okán párhuzamos oltalom is fennállhat (Lontai et al. 2017).

\section{A szoftver mint szerzői mú jellemzői}

A szoftver a jelenleg uralkodó jogi felfogás szerint szerzői mú (mint például egy irodalmi alkotás). A szoftverre szerzői múként tekintenek a nemzetközi egyezményekben (WIPO Copyright Treaty, The Agreement on Trade-Related Aspects of Intellectual Property Rights), az uniós joganyagban (2009/24/EK irányelv) és a magyar jogszabályokban (Faludi 2005; Gyertyánfy 2020, 58. \$). A szoftver szerzői múvi besorolása azért fontos, mert ez egy mindenkor elválaszthatatlan kapcsolatot jelent az alkotójával. Az alkotó a jelenleg uralkodó felfogás szerint csak természetes személy lehet (Grád-Gyenge 2020).

A szerzői mú létrejövetelével jön létre, azaz nincs hatósági bejelentési kötelezettség és nem támasztható ilyen feltétel egyetlenegy szoftver jogi védelmének elismerése feltételéül sem. Mindez azt jelenti, hogy a szoftver jogi védelme folyamatosan változhat: egy-egy fejlesztés eredményeként eredeti, alkotó jellegú beavatkozás jogi védelmet élvez. A szakirodalom szerint egyébként a szoftver egyéni eredeti jellegű megalkotása mint mérce alacsonyan található, azaz könnyen elérhető a védelem. Utalhatunk itt a Szerzői Jogi Szakértői Testület 20/2004. sz. ügyére, amelynek tárgya egy számítógépes egyedi betúkészlet volt, mely az SZJSZT szerint önálló alkotásnak minősült. Az SZJSZT 38/2004. - támaszkodva az előző szakértői véleményre - akként foglalt állást, hogy a grafikai fontokra akár a számítógépi programra vonatkozó védelem is kiterjed (Gyertyánfy 2020).

A szerzői művek elemi jellemzője az egyéni, eredeti jelleg, ennek alapján részesül a szoftver jogi védelemben: szoftvernek a forráskód és a tárgyi kód együttesét tekintjük. A szerzői jogi védelem kiterjed a dokumentációra is. Az uniós joganyag implementációja nyomán az Szjt. (1999. évi LXXVI. törvény a szerzői jogról, továbbiakban: Szjt.) 58. $\$(1)$ bekezdése külön kiemeli, hogy a szerzői jogi rendelkezéseket alkalmazni kell a szoftver csatlakozó felületének alapját képező ötletre, elvre, elgondolásra, eljárásra, múködési módszerre vagy matematikai mûveletre is (összefoglalóan: csatlakozó felület, interfész).

Fontos hangsúlyozni, hogy az egyéni eredeti jelleg nemcsak magával a szoftverrel mint egésszel szemben értelmezhető, hanem egyes részelemek tekintetében is. Azaz egy-egy vizuális megjelenés, audiomegoldás is lehet önálló mú. Sőt a fejlesztés egyes folyamatai, részfázisai is alkalmasak arra, hogy szerzői jogi védelem tárgyai legyenek (Gyertyánfy 2020).

Az Szjt. önálló fejezetet szentel a szoftverre irányadó sajátos szabályoknak. A szoftver szerzőjét - az általános szabályokkal ellentétben - nem illeti meg a többszörözésre, az átdolgozásra, a feldolgozásra, a fordításra, a szoftver bármely más módosítására - ideértve a hiba kijavítását is -, valamint ezek eredményének többszörözésére való kizárólagos jog annyiban, amennyiben e felhasználási cselekményeket a szoftvert jogszerúen megszerző személy a szoftver rendeltetésével összhangban végzi [Szjt. 59. \$ (1) bek.]. A felhasználási szerződésben sem zárható ki a felhasználó biztonsági másolatkészítési joga, ha az a felhasználáshoz szükséges [Szjt. 59. \$ (2) bek.]. Továbbá az Szjt. olyan esetköröket határoz meg, amelyek esetében nem szükséges a szerző engedélye. Egy bírósági döntés tényállása szerint a jogszerúen használt szoftverbe a felhasználó további funkciót épített be, ami jogi értelemben az eredeti mú átdolgozásának minősült a forráskód érintésével. A bíróság álláspontja szerint ez jogsértő, amennyiben ez túlmutat a felhasználási célon, így megsértette a jogosult vagyoni jogait [Fővárosi Ítélőtábla Pf. 20.644/2018/6.].

\section{A dekompiláció (visszafejtés) kérdése}

A szoftver alapjait képező elvek, elgondolások és algoritmusok önálló szerzői jogi védelemben nem részesülnek. Ezért a szoftver visszafejtése főszabály szerint jogszerűen nem történhet meg. Az Szjt. ismeri azonban a jogszerú visszafejtés lehetőségét, melyhez nem szükséges a szerző engedélye. Ez csak abban az esetben lehetséges, amely elengedhetetlen az önállóan megalkotott szoftvernek más szoftverekkel való együttes múködtetéséhez szükséges információ megszerzése érdekében, feltéve, hogy e felhasználási cselekményeket a jogszerú felhasználó vagy a szoft- 
ver példányának felhasználására jogosult más személy, vagy az ő megbízottjuk végzi; az együttes múködtetéshez szükséges információ az említett személyek számára nem vált könnyen hozzáférhetővé; és e felhasználási cselekmények a szoftvernek azokra a részeire korlátozódnak, amelyek az együttes múködtetés biztosításához szükségesek [Szjt. 60. \$ (1) bek.]. Korlátként állítja fel ehhez kapcsolódóan az Szjt., hogy a megszerzett információ nem használható fel az önállóan megalkotott szoftverrel való együttes múködtetésen kívüli célra; mással nem közölhető, kivéve, ha az önállóan megalkotott szoftverrel való együttes múködtetés ezt szükségessé teszi; nem használható fel a kifejezési formájában lényegében hasonló másik szoftver kifejlesztéséhez, előállításához és forgalomba hozatalához, sem pedig a szerzői jog megsértésével járó bármely más cselekményhez [Szjt. 60. $\$(2)$ bek.].

Mindezek alapján a számítógépes programalkotás önálló szerzői mú, olyan keretként jelenik meg a joggyakorlatban, amely széles körben képes magába foglalni az egyéni eredeti jelleggel és egyéni alkotói munkán alapuló alkotásokat. Nyilvántartásba-vétel hiányában az egyedi fejlesztési fázisok is önálló védelemre alkalmas megoldások lehetnek, amelyek a mesterségesintelligencia-fejlesztések során azt jelentheti, hogy napról napra is változhat a védelem tárgya, és folyamatos, több személy általi fejlesztés eredményeképpen pedig az alkotó személye is változhat.

\section{A gyưjteményes mú és adatbázisok védelme}

Az Szjt. szerzői jogi védelemben részesíti a gyüjteményt, ha tartalmának összeválogatása, elrendezése vagy szerkesztése egyéni, eredeti jellegü (gyüjteményes mü). A védelem a gyújteményes múvet megilleti akkor is, ha annak részei, tartalmi elemei nem részesülnek, illetve nem részesülhetnek szerzői jogi védelemben; ezekben az esetekben a mü jogosultja a szerkesztő [Szjt. 7. \$ (1)-(3) bek.]. Az ilyen védelemhez elegendő a válogatás vagy a szerkesztés egyéni, eredeti jellege, ilyen például az antológia [SZJSZT 29/2004.]. Véleményünk szerint a projektben felépített hálózat ilyennek minősülhet leginkább. A meghatározott időnként újabb és újabb felvételeken tanuló algoritmus olyan gyüjteményt hoz létre, amely védelemben részesíthető, és emellett akár jogilag forgalomképes vagyontárgy is létrejöhet.

$\mathrm{Az}$ Szjt. önálló védelemben részesíti az adatbázist is. A törvény definíciója szerint adatbázis: az önálló múvek, adatok vagy egyéb tartalmi elemek valamely rendszer vagy módszer szerint elrendezett gyújteménye, amelynek tartalmi elemeihez - számítástechnikai eszközökkel vagy bármely más módon - egyedileg hozzá lehet férni [Szjt. 60/A. \$ (1) bek.]. Ez jogilag nem szerzői jog, hanem csak kapcsolódó jog, mivel az egyéni alkotói munka nem olyan fokban jelenik meg ezeknél az adatbázisoknál, mint egy önálló szerzói mú esetében. Viszont fontos az, hogy a szerkesztésben az egyéni eredeti jellegnek meg kell jelennie, ennek hiányában kapcsolódó jogi védelem sem áll fenn [BDT2016. 3424.]. Fontos az is, hogy az elemeket valamiféle rendszer vagy módszer szerint rendezik el, amelynek folytán az egyes elemekhez hozzá lehet férni (akár elektronikus vagy számítástechnikai eszközzel) [SZJSZT 29/2004.]. Amennyiben a számítástechnikai eszközökkel hozzáférhető tartalmú adatbázis előállításához vagy múködtetéséhez szoftvert használnak fel, nem az adatbázisra, hanem a szoftverre vonatkozó szabályok alkalmazandóak [Szjt. 60/A. (3) bek.]. A vagyoni jogok átruházhatóak [Szjt. 61. \$(2) bek.].

Kiegészítő megoldás lehet az Szjt. által önálló sui generis védelemben részesített gyüjteményes münek minösülő adatbázis [Szjt. 61. \$]. A vagyoni jogok ennél a formánál is átruházhatóak.

A kapcsolódó jogi védelem illeti meg az adatbázis elo"állitóit, ha az adatbázisuk tartalmának megszerzése, ellenőrzése vagy megjelenítése jelentős ráfordítást igényelt [Szjt. 84/A. \$]. Az adatbázis fogalmára a fenti fogalom irányadó. Az ilyen típusú védelem megújul, amennyiben újból ilyen tevékenységgel dolgoznak az adatbázison [SZJSZT 29/2004. Szjt. 84/D. \$ (2) bek.]. A jelentős ráfordításnak - melyet a joggyakorlat megszorítóan értelmez (Gyertyánfy 2020) - az adatbázis összeállításánál kell megvalósulnia, és nem az alapadatok létrehozásánál; az sem zárható ki, hogy a két személy ugyanaz legyen, mindkét védelem megilleti [SZJSZT 29/2004. és EuB C-203/02. sz. ügy]. Ez a védelem a jogi személyt is megilletheti [Szjt. 84/A. $\$(6)$ bek.]. A vagyoni jogok ilyen esetben csak a többszörözésre és a kimásolásra terjednek ki. [Ennek feltételeit részletesen lásd: Szjt. 84/ A-E. $\$ S S$.]

A védelmi formákon kívül esnek az algoritmus és az egyéb matematikai számítások. Ezek a szoftver jogi védelme alá nem sorolhatóak, és kapcsolódó jogi szabályozás sincs ezekre a formákra. Az azonban vélhetően nem kizárható, hogy ezek alkalmazásával létrejött adatbázis, gyüjteményes mû szerzői jogi oltalomban részesüljön. Mindezek hiányában, a legvégső forma az üzleti titok (know-how) minósítés. Ebben az esetben egyébként maga a know-how törvényi szabály alapján forgalomképes jogként viselkedik [2018. évi LIV. törvény 4.\$].

\section{Összefoglalás és megoldási javaslat}

A projekt által kifejlesztett megoldás előremutató orvostudományi és gyakorlati megoldást jelent. Ha jogi analógiát szeretnénk erre használni, akkor úgy képzelhető el a múködése, mintha lenne egy olyan megoldásunk, amely az összes hazai bírósági döntést elemezve egyes jogi területeken választ képes adni a felmerülő jogi problémára úgy, hogy minden nap a legújabb bírói döntéseket is megtanulja és alkalmazza. A gyakorlati alkalmazhatóság fontos szempont, és nem kíván külön magyarázatot egy ilyen rendszer országos - minden intézményre kiterjedő - alkalmazásának előnye. A felvetett problémára hatékony jogi megoldás szükséges. 
A fent bemutatott védelmi formák közös jellemzője, hogy egymással párhuzamosan is fennállhatnak, és jelentős személyi átfedésben lehetnek egymással. A legfontosabb probléma a párhuzamos - összefoglalóan - szerzői jogi védelem kapcsán az, hogy hogyan különíthetőek el az egyes személyi hozzájárulások (alkotó munkák) a szoftveren, különösen akkor, ha nyílt forráskódú szoftverról van szó.

Amennyiben ilyen közös alkotás születik, akkor közös mû jön létre (közös mû vagy együttes mú). Ez alól egyetlen kivételt lehet tenni, ha munkaviszonyban - vagy más hasonló jogviszonyban, például közszolgálati jogviszonyban - a munkáltatót illeti meg a szoftverhez kapcsolódó vagyoni jogok [Szjt. 30. \$].

A másik fontos következmény a szerzői jogokkal kapcsolatos. A szerzőt személyhez füződő és vagyoni jogok illetik meg. A szoftver esetében a vagyoni jogok mint egész átruházhatóak. Ez azt jelenti, hogy a hasznosításhoz nem feltétlenül kell a szerző hozzájárulása. Azonban minél inkább csorbul ez a védelem (azaz az alternatív oltalmi formák fenti esetein), annál inkább szúkülnek a szerző jogai és a jogi védelem szintje.

A mesterségesintelligencia-szoftver kapcsán véleményünk szerint a szoftveri minősítés a legoptimálisabb. A vagyoni jogok megszerezhetőek teljes egészében, és érdemes szerződés útján tisztázni az egyes kapcsolódó felhasználási, szerzőségi jogokat. Nyílt forráskódú szoftvernél ez a probléma nem kerül előtérbe, mivel elérhetó a forráskód.

A vizsgált mesterségesintelligencia-szoftver kapcsán az elkészült diagnózisok folyamatát kell megvizsgálni. Ha a szoftver önmagában nem képes erre, csak a keretet adja, akkor nem lesz része az elkészült képek jogosultjainak (pl.: a fényképezőgép gyártója sem lesz a fotó szerzője). $\mathrm{Ha}$ az algoritmus a szoftver része, akkor viszont igen, mert a rendszerezési elv kidolgozásában ebból a szempontból részt vett. Mindezeket érdemes a felhasználási szerződésben pontosan rögzíteni, a folyamat teljes ismerete alapján.

A jogi védelem egy másik vizsgálandó szempontja az, hogy a tanulási folyamat, amely tökéletesíti a mesterséges intelligenciát, mely esetben hoz létre új szerzői múvet. Ha minden esetben, akkor előfordulhat, hogy minden nap új szoftver jön létre, új védendő szellemi alkotás. Az esetlegesen felmerülő jogkövetkezmények miatt azonban szükséges rögzíteni egy fejlesztési fázist és szakaszt, amely a védelem alapja lesz, mert ez a jövőbeni vitás kérdéseket megelőzheti. Természetesen a szerződéses környezet ezekre is választ tud adni. De vajon minden esetre gondol a mesterséges intelligencia fejlesztője és alkalmazója? Vagy a választ törvényekben, nemzetközi szinten szükséges rögzíteni? A kérdés sürgető, mert a mesterséges intelligencia alkalmazásának előnyei kikövetelik a jogi megoldás mielőbbi rendezését. A fenti sorok ehhez kívántak általános megközelítésben az uniós és közjogi keretrendszer felvázolásával, majd a hatályos szabályozás vonatkozásában pedig elsődlegesen a szellemi alkotások joga szerint biztosítható védelem szempontjából adalékot nyújtani a konkrét projekt kapcsán.

\section{Köszönetnyilvánítás}

A kutatást az Innovációs és Technológiai Minisztérium Tématerületi Kiválósági Programja finanszírozta, a Semmelweis Egyetem Digitáis BIOmarker tématerületi programja keretében. NKFIH-837-6/2019

The research was financed by the Research Excellence Programme of the Ministry for Innovation and Technology in Hungary, within the framework of the Digital Biomarker thematic programme of the Semmelweis University.

NKFIH-837-6/2019

\section{Irodalomjegyzék}

Adatstratégia (2020) A Bizottság közleménye az Európai Parlamentnek, a Tanácsnak, az Európai Gazdasági és Szociális Bizottságnak és a Régiók Bizottságának. Európai adatstratégia, Brüsszel, 2020. 02. 19. COM (2020) 66

Auer Á. \& Orbán E. (2020) Zárókőszerep az uniós alapjogvédelemben? Újabb fejlemények a német Szövetségi Alkotmánybíróságnak az uniós joghoz füződő viszonyában. A felejtéshez való jog I-II. Jogtudományi Közlöny, Vol. 75. No. 9. pp. 385-397.

Auer Á. \& Papp T. (2014) Gondolatok a software jogi megítéléséról a gyakorlat tükrében. De iurisprudentia et iure publico, Vol. VIII. No. 1. pp. 1-8.

EP állásfoglalás (2018) Az Európai Parlament 2017. február 16-i állásfoglalása a Bizottságnak szóló ajánlásokkal a robotikára vonatkozó polgári jogi szabályokról (2015/2103(INL)). https://www.europarl.europa.eu/doceo/document/TA-8-2017-0051_HU.html

Faludi G. (2005) A szoftver szerzői jogi szabályozása. Infokommunikáció és Jog, Vol. 3. No. 3. pp. 2-5.

Fehér könyv (2020) Európai Bizottság: Fehér könyv a mesterséges intelligenciáról: a kiválóság és a bizalom európai megközelítése COM (2020) 65. https://ec.europa.eu/info/sites/default/files/commission-white-paper-artificial-intelligence-feb2020_hu.pdf

Gaszt Cs. (2019) A mesterséges intelligencia szabályozási kérdései, különös tekintettel a robotikára. Infokommunikáció és Jog, Vol. 17. No. 1. pp. 21-26.

Grád-Gyenge A. (2020) Egy modern szerzői jog. Wolters Kluwer, Budapest

Gyertyánfy P. (szerk.) (2020) Nagykommentár a szerzői jogról szóló 1999. évi LXXVI. törvényhez. CompLex Jogtár, Budapest

Javaslat (2021) Proposal for a regulation of the European Parliament and of the Council laying down harmonised rules on Artificial Intelligence (Artificial Intelligence Act) and amending certain union legislative acts. Com/2021/206 final. https://eur-lex.europa.eu/ legal-content/EN/ALL/?uri=CELLAR:e0649735-a372-11 eb9585-01aa75ed7lal

Jelentés (2020) A Bizottság jelentése az Európai Parlamentnek, és az Európai Gazdasági és Szociális Bizottságnak. Jelentés a mesterséges intelligencia, a dolgok internete és a robotika biztonsági és felelősségi vonatkozásairól. Brüsszel, 2020. 02. 19. COM (2020) 64

Keserű Barna Arnold: A 21. századi technológiai változások hatása a jogalkotásra. Dialóg Campus, Budapest, 2020. pp. 47-51. 
Klein T. \& Tóth A. (szerk.) (2019) Technológia jog - robotjog cyberjog. Wolters Kluwer, Budapest

Kovács L., Czékmann Zs., \& Ritó E. (2020) A mesterséges intelligencia alkalmazásának lehetőségei az államigazgatásban. Infokommunikáció és Jog, Vol. 18. No. 2.

Lontai E., Faludi G., Gyertyánfy P., \& Vékás G. (2017) Polgári jog szerzói jog és iparjogvédelem. ELTE Eötvös Kiadó, Budapest

Pusztahelyi R. (2020) Mesterséges intelligencia által okozott károk: a no-fault kártalanítási rendszer bevezetésének előnyei és hátrányai. Infokommunikáció és Jog, Vol. 18. No. 2.
Scherer, M. (2016) Regulating Artificial Intelligence Systems: Risks, Challenges, Competencies, and Strategies. Harvard Journal of Law \& Technology, Vol. 30. No. 2. pp. 353-400. http://dx.doi. org/10.2139/ssrn.2609777

Schuster, M. (2018) Artificial Intelligence and Patent Ownership. Washington and Lee Law Review, Rev. 1945 Vol. 76. No. 4. 2018/4. pp. 1952-1966.

Szoftver irányelv: 2009/24/EK irányelv

Ződi Zs. (2018) Platformok, robotok és a jog. Gondolat Kiadó, Budapest

A cikk a Creative Commons Attribution 4.0 International License (https://creativecommons.org/licenses/by/4.0/) feltételei szerint publikált Open Access közlemény, melynek szellemében a cikk bármilyen médiumban szabadon felhasználható, megosztható és újraközölhető, feltéve, hogy az eredeti szerző és a közlés helye, illetve a CC License linkje és az esetlegesen végrehajtott módosítások feltüntetésre kerülnek. (SID_1) 